\title{
Determinants of Postharvest Losses in Tomato Production in The Savannah Region of Togo
}

\author{
Mawuena G. Goka, Marie Dufrechou, Pierre Picouet, Kouassi Soncy, and Yaovi Ameyapoh
}

\section{ABSTRACT}

Post-harvest losses have been identified as one of the main causes of food shortage problems in most developing countries and in Togo especially. The aim of this study was to examine the determinants of post-harvest losses in tomato production in the Savannah region of Togo. A standardized structured questionnaire was used to collect data from 25 farmers selected through a combination of purposive and simple random sampling techniques. Descriptive statistics were used to summarize the characteristics of the respondents. Multiple regression analysis was conducted to examine the determinants of postharvest losses of tomatoes. The typical tomato farmer in the locality is 37 years, married, with a household of three people, and having attained a basic level of education. On average, farmers grow tomatoes on a farm of about 2 hectares and have about 10 years of farming experience. The study showed that $42 \%$ of tomatoes during the major season were lost and $90 \%$ during the minor season. From the farmers' point of view, the main sources of losses were rotting and bruising due to improper handling, diseases, and pest attacks. Regression analysis showed that farmer gender, household size, farm size, number of days in storage significantly influenced the level of post-harvest losses. Female gender, farm size, and the number of days in storage were positively associated with losses in tomato production. However, household size, membership in cooperatives, and growing improved varieties reduced post-harvest losses. Limited access to credit, lack of storage facilities, and lack of market access are the main constraints faced by tomato farmers. The study recommended periodic training of producers and membership in cooperatives. Education of farmers on growing improved varieties of tomatoes as well as training in proper processing of tomato fruits and derivatives to reduce post-harvest losses.

Keywords: postharvest losses, savannah region, Togo, tomato.
Submitted : August 16, 2021

Published : September 08, 2021

ISSN: $2684-1827$

DOI: $10.24018 /$ ejfood.2021.3.5.358

Mawuena G. Goka

LAMICODA, Ecole Supérieure des Techniques Biologiques et Alimentaires (ESTBA), 1515, Lomé, Togo.

(e-mail: liebe176@yahoo.fr)

Marie Dufrechou

USC 1422 GRAPPE, INRA,

Ecole Supérieure d'Agricultures, SFR

4207 QUASAV, 55 rue Rabelais, BP

30748, 49007 Angers Cedex 01,

France.

(e-mail:

m.dufrechou ${ }^{@}$ groupe-esa.com)

Pierre Picouet

USC 1422 GRAPPE, INRA,

Ecole Supérieure d'Agricultures, SFR 4207 QUASAV, 55 rue Rabelais, BP 30748, 49007 Angers Cedex 01,

France.

(e-mail: p.picouet@ groupe-esa.com)

Kouassi Soncy

LAMICODA, Ecole Supérieure des

Techniques Biologiques et Alimentaires (ESTBA), 1515, Lomé, Togo.

(e-mail: soncymarcellin@ ${ }^{\circledR}$ yahoo.fr)

Yaovi Ameyapoh*

LAMICODA, Ecole Supérieure des

Techniques Biologiques et Alimentaires (ESTBA), 1515, Lomé, Togo.

(e-mail: ameyapoh.blaise@ gmail.com)

*Corresponding Author

\section{INTRODUCTION}

Fresh vegetables and fruits are essential sources of vitamins and minerals for humans[1]. Tomatoes are a widely consumed vegetable fruit worldwide. In 2017, its production was estimated at 182 million tons worldwide, including 21 million tons in Africa and 5,564 tons in Togo [2]. Tomatoes are a very important component of food consumed at the household level, as evidenced by the fact that many Ghanaian dishes contain tomatoes as an ingredient [3]. Tomatoes are one of the most post-harvest loss products in the fruit and vegetable supply chains of sub-Saharan Africa [4]; [5]. According to [6], post-harvest losses in the fresh tomato supply chain in Africa occurs mainly at the pre-consumer level. [7] indicated in their research report that post-harvest losses are highest for tomatoes recording up to $20 \%$ after 5 days of harvest. Several factors are involved in the post- harvest loss of tomatoes, ranging from growing conditions to handling at the retail level. These factors include high field temperatures on the crop before harvest, pest and disease attacks on the tomato plants. Also, the variety of tomato grown can affect the level of post-harvest losses, as each variety is identified by different characteristics such as firmness, disease resistance, among others, which impact post-harvest losses [8]. In addition, a study by [9] showed that the longer the distance between the farm and the market, the greater the losses due to the resulting tomato congestion and heat build-up. [10] also noted that the type and amount of labor used in harvesting played a key role in post-harvest losses. Skilled workers pick and handle the product carefully and, therefore, cause little damage to the fruit. Therefore, they recommended the use of skilled workers if post-harvest losses are to be minimized. Tomato fruits should be harvested in the green ripe state for long-distance marketing and at the fully 
ripe stage for fresh consumption to reduce post-harvest losses [11]. [12] recommended that tomato growers harvest ripe fruit in the morning when the temperature is cool to reduce losses.

In Togo, the total area sown in 2019 is 1610 hectares and the national average yield is $11 \mathrm{t} / \mathrm{ha}$. Three (3) local varieties (Aklikonvi, Tohounvi, Pomvi) and other improved varieties (Pectomech, Roma) are grown [13]. These tomatoes are consumed in different forms: raw, dried, or puree. The production of fresh tomatoes in the Savannah region of northern Togo is a source of livelihood and income for a large number of producers as well as for agents involved in its distribution and marketing throughout the country. Despite its richness in micronutrients, tomato production remains seasonal, artisanal, and unorganized in Togo. The peak period for tomato cultivation is from August to October and during this period, tomato losses are significant. In addition, climatic hazards cause droughts in the cultivation areas. Currently, there is little data on the evaluation of post-harvest losses of tomatoes. This study was designed to assess the factors that influence post-harvest losses of fresh tomatoes at the farm level. Specifically, the study sought to determine the effects of losses on tomato growers' incomes and the key factors that explain these losses.

\section{MATERIALS AND METHODS}

\section{A. Study Areas}

The study was conducted in the Savannah region in the extreme north of Togo. This region extends between $0^{\circ}$ and $1^{\circ}$ East longitude and $10^{\circ}$ and $11^{\circ}$ latitude and covers an area of $8,533 \mathrm{~km} 2$, i.e., $15 \%$ of the national territory. It is bordered to the North by Burkina Faso, to the East by Benin, to the West by Ghana, and to the South by the Kara region. The mainly rural population was 828,224 in 2010 and is dominated by women, whose number is estimated at 430,228 against 397,996 men. The climate is tropical Sudanese and is characterized by a long dry season that extends from October to May and is marked by the Harmattan, as well as high insolation with temperatures sometimes reaching $45^{\circ} \mathrm{C}$. The short rainy season, marked by the Monsoon, extends from May to September. Since 2000, tomato cultivation has intensified around Dapaong, the capital of the Tône prefecture, as well as in the Savannah region, which exports a significant amount of its production to Lome. Tomatoes are grown throughout the district, with a strong concentration in the Timbou, Safobe, Nioukpourma, Nassongue, and Namoudjoaga communities.

Each year, more than $30 \%$ of tomatoes are wasted. Some farmers refuse to harvest because of the very low market price for this commodity. Tomatoes are produced throughout the year in the district in valley bottoms and with small-scale local irrigation systems [14].

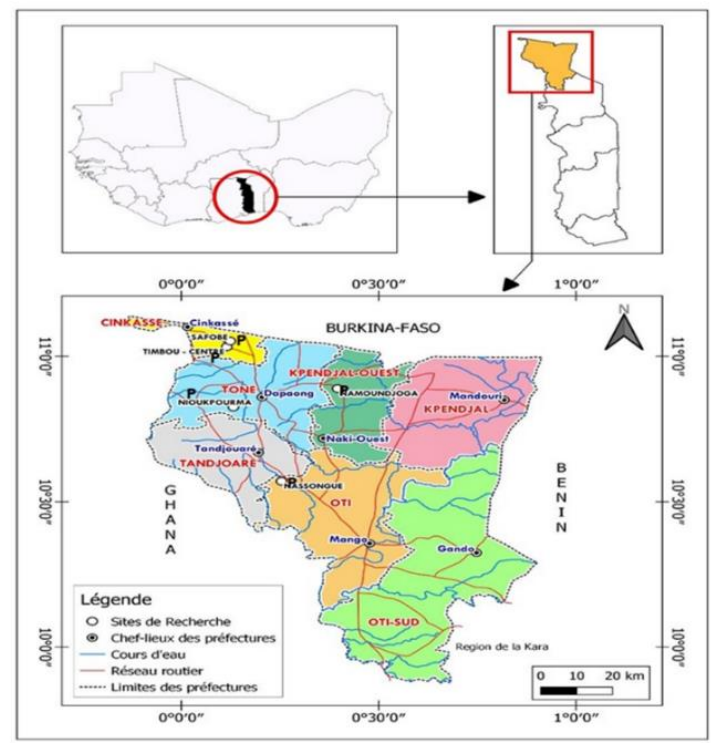

Fig. 1. Map of the Savannah Region (Source: Researchgate.net).

\section{B. Method of Data Collection and Analytical Procedure}

Primary data were obtained from tomato growers through personal interviews using a standardized structured questionnaire. In consultation with the local agricultural financing incentive scheme officers (MIFA) at the district, a list of communities known to produce tomatoes was prepared and a simple random sampling technique was used to select five communities, as follows: Timbou, Safobe, Nioukpourma, Nassongue, and Namoudjoaga. A list of tomato growers at the community level was obtained and a systematic random sampling technique was used to select 25 farmers from each community. The questionnaire used for the interview was designed to collect information on the general characteristics of the respondents, information on production, post-harvest losses, and constraints faced by tomato farmers. Interviews were conducted in the local language to avoid creating a language barrier. Interviews with key informants (agents of the Technical Support Council Institute (ICAT)) were also conducted to collect technical information on tomato production to verify and validate the accuracy of some of the information provided by farmers. Descriptive statistics such as arithmetic mean standard deviation, as well as frequency distribution tables and charts, were employed to summarize the characteristics of the respondents. The economic value of fresh tomato fruits lost was obtained by multiplying the physical quantity of fruits lost by the average prevailing market price. Multiple regression analysis was employed to determine the main factors that influence postharvest losses. The model used was specified in the double logarithmic form as:

\section{Ln $P H L=b 0+b 1 \operatorname{LnX} 1+b 2 \operatorname{LnX} 2+b 3 \operatorname{LnX} 3+b 4 \operatorname{LnX} 4+b 5 \operatorname{Ln}$ $X 5+b 6 \operatorname{Ln} X 6+\mu$

where Ln denotes natural logarithm; PHL= postharvest losses $(\mathrm{kg}) ; \mathrm{X} 1=$ variety of tomato grown $(1=$ if Improved variety; 0 if otherwise), X2= type of labour used for harvesting (1= family labour; 0 if otherwise); X3= time between harvesting and selling of produce (days); X4= farm size (acres); X5= distance from farm to market $(\mathrm{km})$; X6 = member of Farmer Based Organization (FBO) $(1=$ Yes; $0=$ No); $\mu=$ error term. 
The double logarithmic functional form is usually preferred in the empirical analysis since coefficients are easy to interpret; it also has the added advantage of reducing the incidence of multicollinearity. The model was estimated using the ordinary least squares method. A five-point Likert scale was used to assess the constraints faced by tomato producers in the district.

\section{RESULTS AND DISCUSSION}

\section{A. Characteristics of Farmers}

Tomato production in the Savannah region is dominated by men; only $20 \%$ of respondents were women. However, most of these men work with their wives on their tomato farms. A typical tomato farmer is about 36 years old, has a basic level of education, and a household of four people (see Table I). Out of about 2 ha of farmland owned by a typical farmer, about 1.5 ha was devoted to tomato cultivation, implying that the farmers are largely large and medium tomato producers. Annual household income was estimated at 196180 CFA (354.75 USD), or about 49045 CFA (88.68 USD) per capita per year. From this figure, it can be deduced that, on average, tomato growers are quite poor, living on less than 7.39 USD per month per person.

TABLE I: SUMMARY STATISTICS OF THE SOCIOECONOMIC CHARACTERISTICS OF RESPONDENTS

\begin{tabular}{ccccc}
\hline Variable & Min & Max & Mean & $\begin{array}{c}\text { Std. } \\
\text { Deviation }\end{array}$ \\
\hline Age (years) & 27 & 49 & 35.7 & 7.23 \\
Household size & 2 & 4 & 3 & 0.94 \\
$\begin{array}{c}\text { Years of } \\
\text { education }\end{array}$ & 0 & 9 & 3.30 & 3.43 \\
$\begin{array}{c}\text { Annual income } \\
\text { (Francs CFA) }\end{array}$ & 75000 & 350000 & 196180 & 87.822 \\
$\begin{array}{c}\text { Farm size (Ha) } \\
\text { Land owned by } \\
\text { household (ha) }\end{array}$ & 0.75 & 2 & 1.5 & 0.55 \\
\hline
\end{tabular}

Source : Survey data (2020).

\section{B. Causes of Postharvest Losses}

Farmers were given options to select the main cause of post-harvest losses in tomato production. According to their ranking, postharvest losses were mainly the result of rot and bruising (mechanical damage), which were mainly caused by farm activities (Fig. 2). Farmers indicated that rot was the result of excessive use of chemical sprays (herbicides and insecticides), excessive watering, and drought due to climate. Bruising, on the other hand, was the result of poor staking and handling during harvesting and sorting. From the farmers' point of view, the four most critical secondary factors that had a significant impact on post-harvest losses in tomato production were lack of market for the produce, unreliable means of transporting the produce to market, long distances between production and market centers, and the harvesting technique adopted (see Table II). From this table, it can be deduced that farmers consider problems of untimely harvesting as the main cause of post-harvest losses in tomato production. The elements they control for are just the type of variety grown and that is considered to have a low or minimal impact on post-harvest losses.
TABLE II: CONTRIBUTION OF SECONDARY FACTOR TO POSTHARVEST LOSSES

\begin{tabular}{cccccc}
\hline Factor & $\begin{array}{c}\text { Very } \\
\text { high }\end{array}$ & High & Moderate & Low & $\begin{array}{c}\text { Very } \\
\text { Low }\end{array}$ \\
\hline $\begin{array}{c}\text { Lack of market } \\
\text { avenue }\end{array}$ & 0 & 15 & 5 & 4 & 1 \\
$\begin{array}{c}\text { Unreliable means } \\
\text { of transport }\end{array}$ & 0 & 17 & 3 & 1 & 4 \\
$\begin{array}{c}\text { Longer distance to } \\
\text { market }\end{array}$ & 0 & 21 & 4 & 0 & 0 \\
$\begin{array}{c}\text { Untimely harvest } \\
\text { Type of variety } \\
\text { used }\end{array}$ & 0 & 24 & 1 & 0 & 0 \\
$\begin{array}{c}\text { Poor harvesting } \\
\text { technique }\end{array}$ & 0 & 19 & 3 & 3 & 0
\end{tabular}

Source: Survey data (2020).

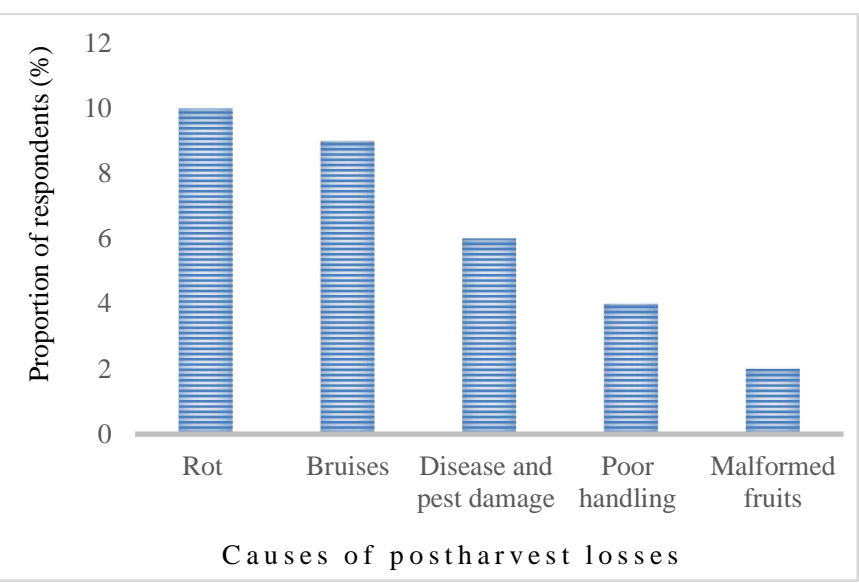

Fig. 2. Primary Causes Of Postharvest Losses In Tomato Production. Source: Generated From Field Data (2021).

Our results found are partially consistent with those found by [15] who found that three critical secondary factors that had a significant impact on postharvest losses in tomato production are lack of market for the produce, unreliable means of transporting the produce to market, and long distances between production centers and market centers. In addition, their farmers consider marketing problems as their main cause of losses, and the elements they controlled such as harvesting time, type of variety grown, and harvesting technique adopted are rather considered to have a low impact on postharvest losses.

\section{Analysis of Tomato Output, Revenue, and Postharvest Losses}

Table III summarizes production information, income obtained from tomato production, and losses during the 2020 agricultural season. The results indicated that the average area of land put under tomato cultivation was about $1 / 2$ ha during the major and minor seasons. On average, the total fresh tomato production obtained during the major season was $12,000 \mathrm{~kg}$, compared to $2,000 \mathrm{~kg}$ during the minor season. The average yield was estimated at $6,000 \mathrm{~kg} / \mathrm{ha}$ for the major season and $125 \mathrm{~kg} / \mathrm{ha}$ for the minor season. The amount of production lost in the major season was $5,000 \mathrm{~kg}$ and its value in monetary terms was 225,000 CFA francs. This represents a loss of $42 \%$ of the harvested product. The amount of production lost during the short season was $1,800 \mathrm{~kg}$, with a value of 13,000 CFA francs, or about $90 \%$ of the product harvested. On average, the quantity sold during the main season was 7,000 kg for a value of 315,000 CFA francs and that of the second season was $200 \mathrm{~kg}$ for a value of 117,000 CFA francs. The potential income that could have been 
generated in the absence of post-harvest losses was estimated at 540,000 CFA francs for the major season and 130,000 CFA francs for the minor season. This means that farmers lost about $42 \%$ of the potential income from tomato production in the major season and $90 \%$ in the minor season. Fig. 3 and 4 indicated that on a per hectare basis, the number of tomatoes lost during the main season was about $2,500 \mathrm{~kg}$, worth about 112,500 francs CFA. During the short season, only $108 \mathrm{~kg}$ of tomatoes (worth 780 francs CFA) were lost per cultivated hectare. This implies that due to post-harvest losses, tomato growers received only $58 \%$ of the potential income during the major season and $10 \%$ during the minor season per hectare (Fig. 3).

TABLE III: ANALYSIS OF TOMATO OUTPUT AND POSTHARVEST LOSSES FOR THE 2020 CROPPING SEASON

\begin{tabular}{ccc}
\hline Variable & Major season & Minor season \\
\hline Land area (ha) & 0.50 & 0.06 \\
Output (kg) & 12,000 & 2,000 \\
Quantity of output lost (kg) & $5,000(41.67 \%)$ & $1,800(90 \%)$ \\
Quantity sold (kg) & 7,000 & 200 \\
Unit Price (CFA /100kg) & 45 & 65 \\
Revenue obtained (CFA) & 315,000 & 117,000 \\
Value of losses des (CFA) & 225,000 & 13,000 \\
Potential revenue (CFA) & 540,000 & 130,000 \\
\hline Source: Survey data(2020). & &
\end{tabular}

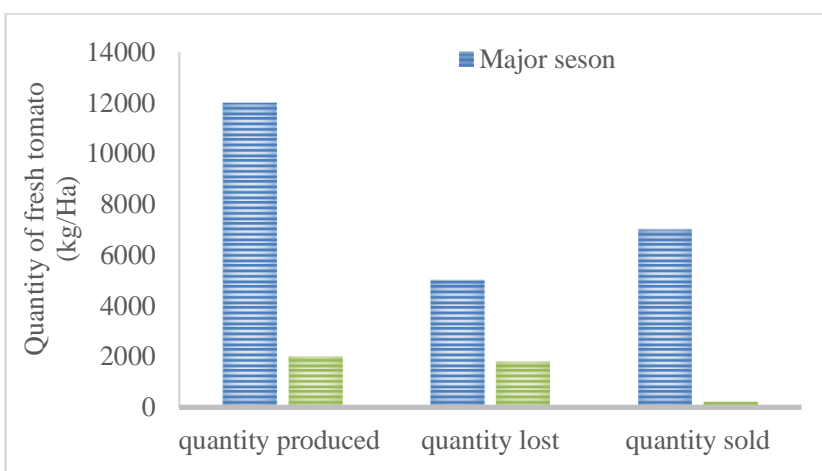

Fig. 3. Analysis Of Tomato Yield And Postharvest Losses Per Hectare. Source: Generated From Field Data (2020).

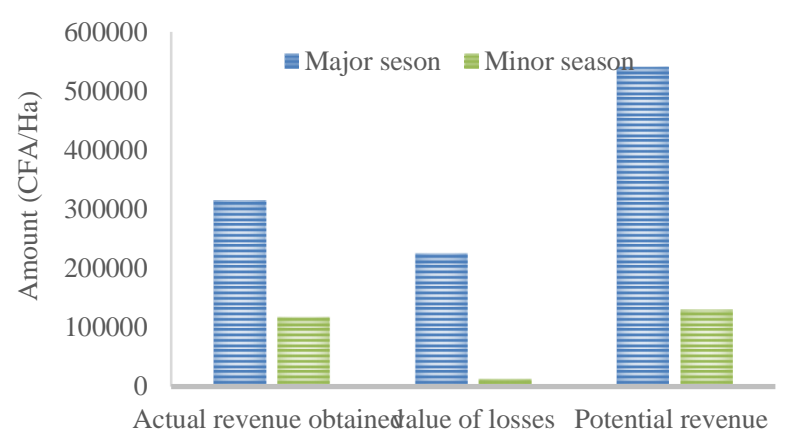

Fig. 4. Analysis Of Actual And Potential Revenue From A Hectare Of Tomatoes. Source: Generated From Field Data (2020).

\section{Determinants of Postharvest Losses}

Table IV provides a summary of the results obtained from the multiple regression analysis. The adjusted coefficient of determination $\left(\mathrm{R}^{2}\right)$ was 0.86 , indicating that $86 \%$ of the variation in the amount of tomato fruit lost during and after harvest was explained by the variables specified in the model. The F-statistics was found to be significant at the $1 \%$ level, implying that all explanatory variables had a significant joint impact on the level of tomatoes lost after harvest.
TABLE IV: REGRESSION ESTIMATED OF THE DETERMINANTS OF TOMATO

\begin{tabular}{ccccc}
\multicolumn{5}{c}{ LOSSES } \\
\hline Variable & Coefficient & Std. Error & $\mathrm{t}$ & $\mathrm{p}>\mathrm{t}$ \\
\hline Constant & 6.750 & 2.623 & 2.573 & 0.017 \\
Gender (1=male, & 0.543 & 0.17497 & 3.105 & 0.005 \\
0=female) & -0.396 & 0.165 & -2.397 & 0.025 \\
Ln Household Size & 0.179 & 0.176 & 1.015 & 0.321 \\
Ln Education (years) & 0.488 & 0.192 & 2.545 & 0.018 \\
Ln Farm size & 0.0656 & 0.345 & 2.056 & 0.015 \\
Ln Day of Storage & 0.01795 & 0.117 & 0.153 & 0.880 \\
Ln Distance to & 0.10705 & 0.21682 & 0.494 & 0.62660 \\
market & 0.15527 & 0.153 & 1.011 & 0.323
\end{tabular}

$\mathrm{R}^{2}=0.862, \mathrm{~F}=19.62 ;($ Significant at $1 \%)$; $\mathrm{SER}=0.212$. Dependent variable : Ln_quantity of tomato fruits lost.

Gender and household size were the demographic variables that had a significant effect on post-harvest losses in tomato production. Female farmers were found to be more prone to high levels of losses than their male counterparts. On the one hand, this contradicts the results of [5] who concluded that there was little or no gender inequality in tomato cultivation and thus no effect of gender on postharvest losses and confirms on the other hand that the results of [2] show that gender does impact production. Tomato harvesting is labor-intensive. In general, male-headed households tend to have a lot of labor hours and more time for tomato harvesting and other agricultural activities, compared to their female counterparts who are naturally not overly strong but also have household/family responsibilities to fulfill. All else being equal, women tend to use a longer period to harvest fruit, resulting in high levels of post-harvest losses. Household size was found to have a significant negative relationship with the level of post-harvest losses as also demonstrated by [3]. Farmers with larger households tend to have lower levels of postharvest losses because they have a relatively large amount of family labor to assist with tomato harvesting to make the process faster and more efficient. Farm size had a significant positive effect on the level of post-harvest losses experienced by farmers. Large farms generally have higher levels of production that require a significant amount of labor for harvesting and transportation. When the household has labor constraints and there is a small delay from traders, farmers typically lose huge volumes of tomatoes. This result is consistent with the findings of [5] and [2] who reported that the larger the area cultivated, the higher the quantity harvested and the higher the risk of losses due to poor handling and lack of adequate storage. The increase in the amount of fruit to be harvested due to the larger farm size leads to an increase in post-harvest losses due to lack of storage facilities and high labor requirements to complete the harvest in time.

It was also found that the number of days that harvested tomatoes were stored until the time of sale had a significant positive effect on the losses incurred. This is consistent with an a priori expectation because tomatoes are a highly perishable commodity due to their shorter shelf life. Membership in a faith-based organization was negatively correlated with the level of post-harvest losses incurred. This means that farmers who join or are members of a faith-based organization are less likely to experience post-harvest losses, as they are in contact with traders' associations that purchase their produce post-harvest from the field. [5] also noted that farmers who belong to agricultural cooperatives get some 
form of assistance in selling their products and consistently have fewer post-harvest losses. Growing improved varieties of tomato (i.e., improved Pectomech and Roma) has been associated with lower levels of losses because these varieties possess certain advantageous qualities that local varieties do not have. Qualities such as firmness, disease resistance, longer shelf life, and thick skin help the fruit withstand pressure during harvest and maintain the quality during storage. This result agrees with the findings of [10] who noted that the variety of tomato grown is an important indicator of the level of post-harvest losses experienced by a farmer.

\section{E. Constraints Faced by Tomato Producers}

Table V shows that tomato farmers in the study area face several challenges. On a five-point Likert scale, lack of storage facilities was ranked as the most important and critical constraint faced by tomato growers in the study area. Farmers considered limited access to finance/credit as the second most important production constraint. Lack of market was considered very high and was therefore ranked as the third most important constraint faced by farmers. A survey by MIFA (2020) also indicated that the high cost of production, unreliable transport, and lack of technology were serious constraints faced by tomato farmers in Togo.

\begin{tabular}{cccccc}
\multicolumn{6}{c}{ TABLE V: CONSTRAINTS IN TOMATO PRODUCTION } \\
\hline Constraint & $\begin{array}{c}\text { Very } \\
\text { high }\end{array}$ & High & Moderate & Low & $\begin{array}{c}\text { Very } \\
\text { Low }\end{array}$ \\
\hline $\begin{array}{c}\text { Lack of storage } \\
\text { facilities }\end{array}$ & 25 & 0 & 0 & 0 & 0 \\
$\begin{array}{c}\text { High cost of } \\
\text { production }\end{array}$ & 0 & 12 & 10 & 3 & 0 \\
$\begin{array}{c}\text { Limited access to } \\
\text { finance }\end{array}$ & 0 & 24 & 1 & 0 & 0 \\
$\begin{array}{c}\text { Lack of market } \\
\text { Unreliable } \\
\text { transport }\end{array}$ & 22 & 1 & 2 & 0 & 0 \\
$\begin{array}{c}\text { Lack of } \\
\text { technology }\end{array}$ & 0 & 17 & 3 & 1 & 4 \\
\hline
\end{tabular}

Source: Field survey(2020).

\section{CONCLUSION}

Our study showed that post-harvest losses are very important in tomato production in the Savannah region. Male gender, household size, cooperatives membership, and cultivation of improved varieties (Pectomech and improved Roma) were associated with lower levels of post-harvest losses. In contrast, farm size and the number of days the product was stored before the sale were associated with higher levels of post-harvest losses in tomato production. To a large extent, a number of the underlying causes of these huge losses are within the control of the local producer. If these factors are well managed, there will be a reduction in post-harvest losses and the availability of raw material will be increased without necessarily cultivating an additional hectare of land. Through the training of faith-based associations, farmers can establish small processing centers that will turn tomatoes into purees and other alternative products when there is no market for fresh fruit. The extension unit of the Ministry of Agriculture should raise awareness and knowledge of the available improved tomato varieties to increase their adoption rate in order to minimize post-harvest losses. Access to water through irrigation must be provided to farmers in order to have water available in times of drought. Farmers should be encouraged to stagger production/schedule production to allow for staged harvesting, thereby reducing labor requirements and postharvest losses. Periodic training on harvesting and proper handling of harvested tomatoes should be organized for farmers. Private entrepreneurs should also be encouraged to invest in the tomato industry by constructing appropriate cold storage facilities at the locality level to help farmers store their harvested produce before it goes to market. This will reduce losses that occur at the farm level.

\section{ACKNOWLEDGMENT}

The authors are grateful to the Risk-Sharing Agricultural Finance Incentive Facility (MIFA) for funding this work. We also thank the Laboratory of Microbiology and Quality Control of Foodstuffs (LAMICODA) of Togo who allowed the realization of this work in their premises.

\section{CONFLICT OF INTEREST}

The authors declare no conflict of interest.

\section{REFERENCES}

[1] A. F. Smith, 1994. The tomato in America: University of Ilorin press ISBN 0-252-07009-7Third World Network (2007), An internationa NGO based in Accra, The history of tomato farming in Ghana: Ghana Today, 23.4 .

[2] FAO, 2018. Basic Harvest and Post-harvest Handling Considerations for Fresh Fruits and Vegetables. Postharvest Training on Food Processing/FAO manual food handling and preservation/CHAPTER 2. FAO, Rome.

[3] J.A. Tambo, T. Gbemu, 2010. Resource-use efficiency in tomato production in the Dangme West District, Ghana. Conference on International Research on Food Security. Tomato from related wild nightshades.

[4] FAOSTAT, 2014. Global tomato production in 2012. Rome, FAO. Online statistical database of the Food Agricultural Organization of the United Nation. [Internet]. Available at: http://faostat.fao.org/. Accessed: 31st July 2014.

[5] H. Affognon, C. Mutungi, P. Saginga, C. Borgmeister, 2015. Unpacking postharvest losses in Sub-Saharan Africa: a meta-analysis. World Development 66, 49-68.

[6] M.S. Sibomana, T.S. Workneh, K. Audain, 2016. A review of postharvest handling and losses in the fresh tomato supply chain: a focus on Sub-Saharan Africa. Food Security, 8(2), 389-404. doi:10.1007/s12571-016-0562-1.

[7] E.J.Z. Robinson, S.L. Kolavalli, 2010. The Case of Tomato in Ghana: Marketing. GSSP Working Paper\#20. Ghana Strategy Support Program (GSSP). GSSP Working Paper No. 20. Accra, Ghana: International Food Program.

[8] Anonymous, 2021: Direction Nationale du Plan, 2005. Lomé, Togo. Direction Générale de la Statistique et de la Comptabilité, Résultats définitifs du RGPH4, 2011 https://togopolitique.org/presentation-dela-region-savanes/\#_ftnref2 (consulté le 25/07/2021).

[9] D.A. Babalola, O.Y. Makinde, B.T. Omonona, M.O. Oyekanmi, 2010.Determinants of postharvest losses in tomato production; A case study of Imeko-Afon local government area of Ogun state. J. Life, Phy. Scl. 3(2); 14-18.

[10] R. Mujib, K. Naushad, J. Inayatullah, 2007. Postharvest Losses in Tomato Crop (A Case of Peshawar Valley). Sarhad. J. Agric. 23: 4. Norman JC (1992). Tropical vegetable crops. Elms Court: Arthur H. Stockwell Ltd.

[11] K.M. Moneruzzaman, A. Hossain, W. Sani, M. Saifuddin, M. Alenazi, 2009. Effect of harvesting and storage conditions on the Postharvest quality of tomato (Lycopersicon esculentum Mill) cv. Roma VF. Austr. J. Crop Sci. 3(2):113-121. 
[12] M.D. Orzolek, M.S. Bogash, M.R. Harsh, F. Lynn, L.F. Kime, K. Jayson, J.K. Harper, 2006. Tomato Production. Agricultural Alternatives Pub. Code \# UA291. pp. 2-3.

[13] FAO, FIDA, MIFA, 2021. Plan de Développement de la filière tomate 2021-2030, version finale, $\mathrm{p} 61$

[14] A.F. Alidu, E.B. Ali , H. Aminu, 2016. Determinants of post-harvest losses among tomato farmers in the Navrongo Municipality in the upper east region. International Biology, Agriculture and Healthcare Journal, 6(12), 14-20.

[15] R. Aidoo, R.A. Danfoku, J.O. Mensah, 2014. Determinants of postharvest losses of tomato production in the Offinso North district of Ghana. Journal of Development and Agricultural Economics. Vol. 6(8), pp. 338-344.

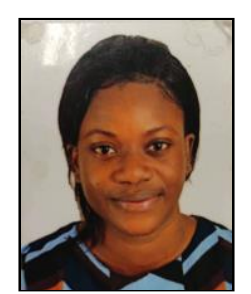

Mawuena Gott'liebe Goka was born in Lomé, Togo in the prefecture of the Gulf on June 17, 1991. She attended the elite elementary school and the protestant college of Lomé-tokoin for her secondary studies. She then went to El-Manar University where she obtained her Bachelor's degree in Biological and Nutritional Sciences in Tunisia in 2013. For her Master's degree in Food Industries, she decided to pursue her research studies at the University Ouaga 1 Pr.Joseph ki-Zerbo in Burkina-Faso in 2017. Because of her prowess, she received a scholarship from the French government in 2017 for the continuation of her research work in Ph.D. thesis in Food Science at the University of Angers-France. In her spare time, Ms. Goka accompanies and trains local producers of AgriResources in her country. She is currently finishing her thesis on the conservation of tomatoes produced in Togo.

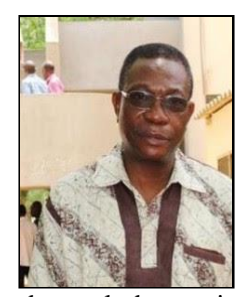

Yaovi Ameyapoh was born on September 18, 1958, in Lomé, Togo. He obtained his Bachelor's degree in Natural Sciences and Psycho-pedagogy at the University of Lome in 1984. He obtained his Master's degree in Applied Biology in 1986, and also his Master's degree in Applied Microbiology and Biochemistry in 1993 at the University of Ouaga 1 Pr.Joseph ki-Zerbo in Burkina-Faso. Then, he continued his research work for a single doctoral degree in Applied Microbiology and Biotechnology at the University of Lome in 2000. Currently, he is Professor of MicrobiologyBiochemistry and holds the position of Deputy Director then Director of the College of Biological and Food Techniques since 2014 (ESTBA), Director of the Laboratory of Microbiology, Quality Control of Foodstuffs (LAMICODA), Scientific Leader of the Master of Research in Microbiology and Cellular Biotechnology at the University of LomeTOGO. He has supervised $15 \mathrm{PhD}$ theses and has published more than 80 articles in indexed scientific journals with impact factors. 